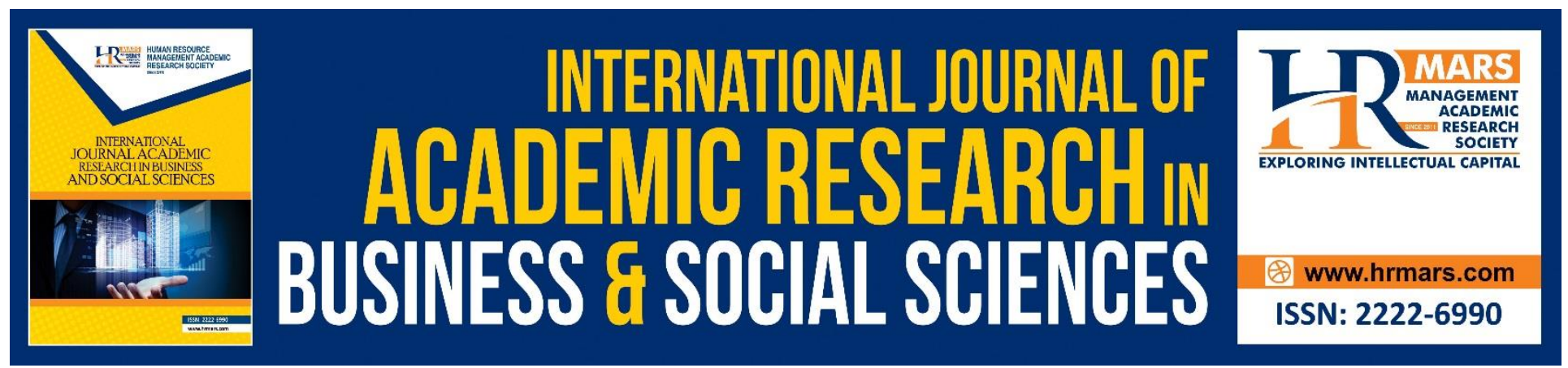

\title{
Enforcement Child-Maintenance Payment Using Judgement Debtor Summons and Judicial Notice: A Penang Case Study
}

\author{
Mohd Hazwan Ismail, Jasni Sulong
}

To Link this Article: http://dx.doi.org/10.6007/IJARBSS/v10-i7/7408

DOI:10.6007/IJARBSS/v10-i7/7408

Received: 06 April 2020, Revised: 10 May 2020, Accepted: 24 June 2020

Published Online: 19 July 2020

In-Text Citation: (Ismail \& Sulong, 2020)

To Cite this Article: Ismail, M. H., \& Sulong, J. (2020). Enforcement Child-Maintenance Payment Using Judgement Debtor Summons and Judicial Notice: A Penang Case Study. International Journal of Academic Research in Business and Social Sciences, 10(7), 187-200.

\section{Copyright: (C) 2020 The Author(s)}

Published by Human Resource Management Academic Research Society (www.hrmars.com)

This article is published under the Creative Commons Attribution (CC BY 4.0) license. Anyone may reproduce, distribute, translate and create derivative works of this article (for both commercial and non-commercial purposes), subject to full attribution to the original publication and authors. The full terms of this license may be seen at: http://creativecommons.org/licences/by/4.0/legalcode

Vol. 10, No. 7, 2020, Pg. 187 - 200

Full Terms \& Conditions of access and use can be found at http://hrmars.com/index.php/pages/detail/publication-ethics 


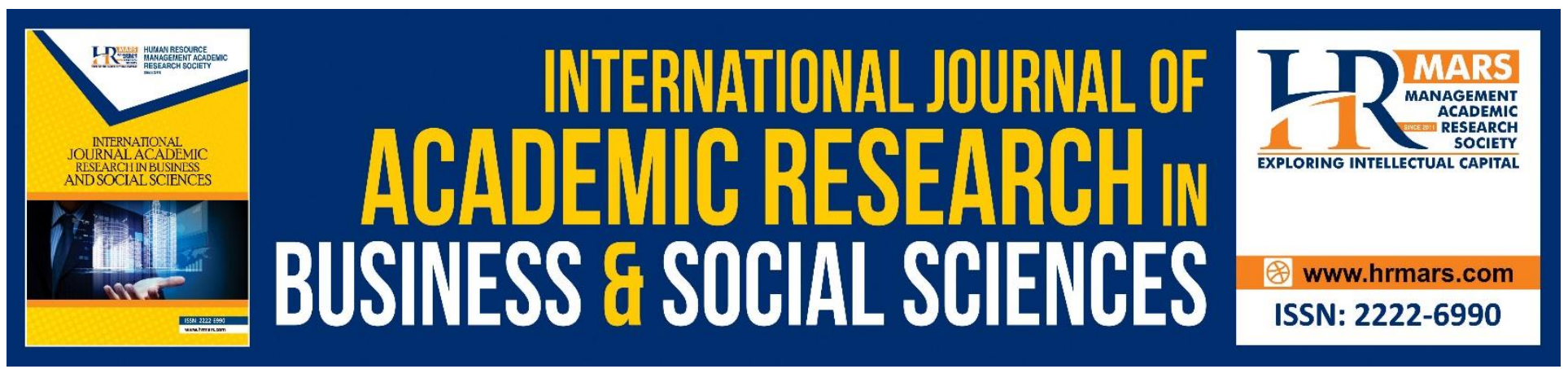

\title{
Enforcement Child-Maintenance Payment Using Judgement Debtor Summons and Judicial Notice: A Penang Case Study
}

\author{
Mohd Hazwan Ismail ${ }^{1}$, Jasni Sulong² \\ ${ }^{1}$ Postgraduate student, Universiti Sains Malaysia, Malaysia, ${ }^{2}$ Associate Professor, Universiti Sains \\ Malaysia, Malaysia. \\ Email: hazwanismail@student.usm.com, ${ }^{2}$ jasni@usm.my.
}

\section{Abstract}

Responsibility to pay for children maintenance is the responsibility of a father, but there are many cases of his failure to do so. This failure can harm the children as well as an ex-wife whom receiving the custody. Therefore, the purpose of this study is to investigate the procedure to claim the rights under the Syariah law in Malaysia generally, and in Penang particularly. In the Shariah Court, many cases claiming for maintenance always schedule later after reconciling case of divorce, which as a result put a delay in restoring maintenance for the children. In the meantime, there were cases where the father was negligent and failed to pay for his son's maintenance for several months. Therefore, the study is trying to highlight the strategy to get the debt as well as the procedure for a custodian to do a claim. The study was done qualitatively by reviewing theories, procedures as well as facts from books, journals, legal documents as well as statistical reports. The data was gathered through library research as well as interviews. Then they were analysed using content analysis to get a reliable finding. It was found that many cases of maintenance default were filed all around states in Malaysia. It involves a large number that has put a strain on children and custodian. Penang Syariah courts have taken an essential move to set up a Family Support Division to help certain wife in claiming the right of her children. Through judgement debtor summon and judgement notice, the shariah court can force a possible father to carry out his religious responsibilities in full of consciousness. Through these law enforcements, a father may be imprisoned for a month or several months according to the default months to pay the arrears. This environment can be a motion for a father to follow the court order and his responsibility in full and on time.

Keywords: Maintenance, Mandatory, Children, Islamic Law, Responsibility, Nafkah.

\section{Introduction}

Children maintenance will be under the responsibility of a father until the former ended from studying and able to get stipend by himself. The conflict always arises due to the split of their parents through divorce. As custody for kids always return to mother, a resentment father will show the 
emotion either by delaying the payment or stop at all. In this case, the lawful step should be taken in handling the matter to guarantee the welfare of children. Especially when it involves a non-working mother who looks after the children, which solely rely on the pay by the father.

In Islam, it is an obligation of a father (Al-Shirbini, 2001). He must pay the maintenance either during marriage or after divorce. For ex-wife, her ex-husband still holds the responsibility until the end of iddah period. While maintenance for children has taken last longer as was mentioned above, until they can survive independently. The parental responsibility continues even though the custody of his kids was given to ex-wife. Any default will be considered as a debt and dissatisfied party can claim arrears and enforcement charge. However, the problem always arises because some father will always find a reason not to pay it in full or to delay it.

This discussion is significant to find ways of handling a default father when paying children maintenance. The failure to pay for children maintenance will lead kids in difficulties to meet their current needs in nutrition, health, education and care. They need support for foods, clothes, shelter, education as well as medical treatment. In the meantime, an ex-mother also has responsibility after due the iddah period which need her to find a source of income for her living which cause custody expense for the kids. Therefore, a sound procedure on child maintenance should be straightened to ensure that the rights of the children are not neglected.

\section{Literature Review}

In Islam, the head in a family is a father who holds the first responsibility towards the family needs such as living maintenance. Therefore, Abu Hassan (2016) has concluded that the responsibility for maintenance has been assigned to male guardian especially father. If there was no father, a grandfather is responsible towards his grandson and then followed by the male relatives in the family. Maintenance (nafkah) is a living expense that includes foods, clothes, shelter, medical treatment, schooling and other necessities. Therefore, in marital matters, a husband is responsible for the maintenance of his wife, and so much more, a father is responsible for the wellbeing of his children. Fail to do so, the Islamic jurists were unanimously agreed that any default will cause debt towards his children. According to Al-Shirbini (2001), pending in the payment of child maintenance will be considered as debt especially when there was a legal ruling that execute the obligation.

According to Zin (2007), the burden to take care of the household maintenance is crucial to ensure the welfare of every dependent are very well preserved. As maintenance involved living needs, it becomes priority matters and were considered among fundamental demands (daruriyyat) under five priorities (awlawiyyat to be preserved) in Islam, that are religion, life, intellect, dignity and wealth. Failure to guarantee those living needs can harm children as well as cause mistreating and abusing. Causing harm to children is worse than wives, because the former are young, fragile and unable to survive on their own. Based on the study by Brooks-Gunn and Duncan (1997), children raised in a poor family environment are more likely to have problems in their development and health. Poor children are more likely to be involved in various social disadvantages.

A study by Nasohah (2018) has reiterated common practice that claim on child maintenance must come after trial on divorce. This is because every derivative claim before the court is always based on 
its primary case to be established. For example, the claim of child maintenance derivates from a divorce case. Thus, the resolution of a divorce case should be held earlier, then will determine the eligibility of the claim of child/wife maintenance that follows. Circumstances that require a step-bystep approach to the claim procedure cause a claim process to be delayed. This is not including a trial period which takes time, based on the complexity of the case and the attitude of the parties involved. Reports from Ismail (2018) and analysis by Asni \& Sulong (2017b) show that cases of delay in making child maintenance decisions often occur and this is not good for them. If the trial takes up to months, then the decision on child maintenance has been made into a delay for a longer period. A bigger case with a higher number of parties involved will lead to some time to resolve.

According to Zin (2007) and Asni \& Sulong (2017a), the bureaucratic issue is one of the problems that lead to the delay in the settlement of child maintenance claims. In addition to the claim that needs to be initiated after the primary case is decided, several forms need to be filled in for proofing the case as well as evidence to prove that the breach has occurred. Besides, there are other factors which are related to humankind and administrative issues such as health issues, absent and change of judges or lawyers. All those procedures and circumstances will bring a trial to delay which has caused difficulties towards children. According to Jamaludin \& Buang (2017) findings, some court adjudicate the dilemma by deciding through an ex-parte proceeding to ensure the welfare of children is in place.

According to Salleh (2018), statistics have reported that arrears of child maintenance involve millions of Ringgits. The value can solve many of the needs of children if they are reimbursed promptly. Among reasons for this situation is that there are orders by the Syariah court which was disregarded by some father, due to his domicile in a different state. As we know that the Syariah laws in Malaysia are enforced according to each state. Different state has its legislation as well as its jurisdiction to enforce the law. Thus, the enforcement is in conflict and required bureaucracy means when its involved parties from different state. Thus, the child maintenance will be accumulated if a father does not pay his monthly commitment. If the default continues from month to month, the value of arrears is increasing which is in line with the value of mistreatment towards his children. This would not just affect the children expenditure during the month, but the domino effect also triggered their current guardian such as mother or grandfather (Makhtar et. all., 2017).

Other studies by Ibrahim \& Mohd (2013) have explained that there is a reason behind cases of default father on his children maintenance. Generally, not all fathers have the same kind of empathy and consideration. So, do in the financial ability, the background of a father as well as his education background will reflect towards his economic capability and the mindfulness. Not to mention if a father has problems at work, not in good health and having bad disciplined in life. Those reasons will influence the father to be insensitive with the needs of his children, thus, become irresponsible. The same echoed was reiterated by Salleh (2018) in the event of a father's failure towards his responsibility. As a result, the attitude will lead to mistreat their children in the financial wants.

\section{Methodology}

This study is a qualitative research method. The approach has opted qualitative by doing observation as well as placing conception of certain occurrence and submission. Qualitative research methods are engaged by focusing mainly on the social elements of the community conducts (Howell, 2013). In 
this mode of observation, the research was done through interpretative and explanatory data. According to Willis (2007), that facts and evidences were derived mainly from secondary sources, which are qualitative and are governed by a variety of factors which are non-tangible and difficult to measure. In this study, two methods are employed in doing research, that is, data compilation and data analysis.

The study applied two methods of data compilation techniques, that are, 'library research' and 'field research.' The methods were done to collect enough and appropriate data to tackle the research objectives of this study. The secondary data which involved various printed materials and documents were gathered through library research. Secondary data means the data is readily available and some of it were findings from previous studies. The data which indicate to the research theme or topic will be screening and scanning to answer research objectives. This means that secondary data is not originally collected but rather obtained from published or unpublished sources. In this study, library materials include data gathered from textbooks, published PhD dissertation, published Master's thesis, published academic papers, the Qur'an, the sunnah, newspaper articles, journals, social media communication (Walliman, 2011).

Meanwhile, for field research, the data were collected through observation and interview with the expert as well as whom directly involved with the study. The method of observation was done directly as one of the researchers is a staff in the Syariah court. Meanwhile, interview method was also used as it was complimentary research method in the social sciences, because they allow a more in-depth, open discussion, and more informal, free interaction between the interviewer and the interviewee. In sum, both methods are essential to obtain primary data. Primary data is the main data that identified as information which was collected during the conduction of a research. In applying interviews, two methods also were applied, that is, face-to-face interview as well as a phone conversation. Beforehand, written question has been be prepared in the form of open-ended query. In this context, structured interview protocols were applied to ensure the development of questions were well structured, planned and organized (Pelto, 2017).

All data will be analysed manually through content analysis. The method was applied by analysing data based on themes, meanings, factors and concepts that are interspersed with the research questions and objectives. Then, the collected qualitative evidences were rearranged into specific groups of theme or elements to reflect on the study objectives. Then it is refined or generalized based on comprehension of the text. In this case, the researcher aimed to detect common words and phrases, as well as by categorizing respondents together, to be able to determine trends and tendencies in the answers of the respondents (Walliman, 2011; Pelto, 2017).

Generally, analysis of qualitative data involve deductive and inductive method. Deductive method is evaluating a group of data to reach a logical true conclusion. Meanwhile, inductive is making extensive generalizations from observations (Pelto, 2017). From that, resolution can be made according to the majority indicators of these data. It is either to agree with the hypothesis or to disagree, supporting from every information that was gathered.

The study was set its limit only in the scope of child maintenance, in Malaysia generally and in Penang particularly. More focus has been given to the practice that has been applied in the state of Penang. 
For future researchers, we nevertheless believe that it is more interesting to extend the study to other states as well, by making a comparative study which may yield a much more exciting finding of the child maintenance perspective.

\section{Child Maintenance Claim in the Syariah Court}

Federal Constitution via Ninth Schedule of Second List (State List) has provided that the child maintenance related to Muslim in Malaysia is under the authority of the state. In applying the jurisdiction given, the Syariah court has sovereignty in hearing the claim or other issues related to child maintenance. The rights were provided under the Islamic Family Law Enactment of every state. Based on Section 61 of the Enactment, the law has empowered the Syariah Court to order payment of maintenance against any person who is liable thereto according to Hukum Syarak. According to Nasohah (2018), when there were arrears, the default father must pay the outstanding amount as soon as possible. Otherwise, legal action from the Shariah court will be applied on him. According to Mat Ali \& Arshad (2014), the Syariah Court is also authorised to order payment of maintenance against the male heirs of the father affinity, if the father was dead or missing, except if the male heirs are proven to be unable to provide maintenance, then, such liability would be shifted to the Baitulmal.

Based on the Islamic Family Law Enactment of every state in Malaysia (ss.73), it shall be the duty of a man to maintain his children, whether they are in his custody or the custody of any other person, either by providing them with such accommodation, clothing, food, medical attention, and education as is reasonable having regard to his means and station in life or by paying the cost thereof. An entitlement of child maintenance can be claimed when his father neglects the duty or after the shariah court has granted the application of divorce to his parent. The Syariah court has jurisdiction in deciding the exact amount of child maintenance after a trial. However, if the amount of claim was made based on a mutual written agreement between spouse, the court will not entertain as it does not carry a weight as the court order (Razali and Sulong, 2016). Hence, the decision by the Syariah court will bound them. Since 2017 till 2019 in Malaysia, there are 6,574 cases of maintenance claim made by wife/kids as statistic below: 
INTERNATIONAL JOURNAL OF ACADEMIC RESEARCH IN BUSINESS AND SOCIAL SCIENCES Vol. 10, No. 7, July, 2020, E-ISSN: 2222-6990 @ 2020 HRMARS

Table 1: Registration and Completion of Maintenance Cases at Syariah Court

\begin{tabular}{|l|c|c|c|c|c|c|}
\hline \multirow{2}{*}{ YEAR } & \multicolumn{2}{|c|}{$\mathbf{2 0 1 7}$} & \multicolumn{2}{c|}{$\mathbf{2 0 1 8}$} & \multicolumn{2}{c|}{$\mathbf{2 0 1 9}$} \\
\cline { 2 - 7 } & REGISTER & RESOLVE & REGISTER & RESOLVE & REGISTER & RESOLVE \\
\hline Perlis & 43 & 33 & 37 & 47 & 31 & 37 \\
\hline Kedah & 18 & 16 & 19 & 20 & 65 & 26 \\
\hline $\begin{array}{l}\text { Pulau } \\
\text { Pinang }\end{array}$ & 76 & 20 & 43 & 30 & 40 & 80 \\
\hline Perak & 164 & 136 & 147 & 106 & 173 & 50 \\
\hline Kelantan & 36 & 42 & 29 & 31 & 53 & 67 \\
\hline Terengganu & 137 & 116 & 157 & 126 & 135 & 145 \\
\hline Pahang & 12 & 29 & 19 & 9 & 25 & 19 \\
\hline Selangor & 219 & 111 & 179 & 239 & 287 & 269 \\
\hline $\begin{array}{l}\text { Wilayah } \\
\text { Persekutuan }\end{array}$ & 109 & 88 & 82 & 94 & 74 & 97 \\
\hline N. Sembilan & 115 & 68 & 56 & 80 & 75 & 83 \\
\hline Melaka & 60 & 55 & 48 & 51 & 45 & 53 \\
\hline Johor & 123 & 181 & 71 & 93 & 51 & 44 \\
\hline Sarawak & 38 & 27 & 44 & 41 & 43 & 54 \\
\hline Sabah & 100 & 80 & 81 & 47 & 96 & 79 \\
\hline TOTAL & $\mathbf{1 , 2 5 0}$ & $\mathbf{1 , 0 0 2}$ & $\mathbf{1 , 0 1 2}$ & $\mathbf{1 , 0 1 4}$ & $\mathbf{1 , 1 9 3}$ & $\mathbf{1 , 1 0 3}$ \\
\hline TOTAL & & & & & & \\
\hline
\end{tabular}

Source: The Syariah Judiciary Department of Malaysian

Based on Table 1 above, the state of Selangor has recorded the highest number of cases registered, as well as the highest in terms of resolved. While the state of Pahang is the state with the least number of cases registered.

Meanwhile from the percentage of resolved cases, some states record higher cases resolution than registered cases on that particular year. This is due to the settlement of outstanding cases from the previous year. This trend has been widely achieved in some states, that is, Kelantan, Wilayah Persekutuan, Negeri Sembilan, Melaka and Johor. This situation shows that the Syariah court has worked hard to resolve the issues of child support and at the same time ensure that their welfare is protected. It is clear from the above data that the highest percentage of resolved case compared to the registration case was achieved by the State of Johor (78\%) and followed by Negeri Sembilan (53.4\%), Wilayah Persekutuan (45.6\%), Kelantan (43\%) and Melaka (23.9\%).

Based on explanation by Minister of Women Development, Family and Society in the Parliament (2019), the Ministry has implemented a few steps to improve the mechanism of enforcement claim on children maintenance issue. The steps that were taken by the Government are:

i. Establish a Family Support Division (BSK) in the Syariah Judiciary Department of Malaysia (JKSM) in 2008, which responsible for assisting the Syariah court in enforcing and executing 
INTERNATIONAL JOURNAL OF ACADEMIC RESEARCH IN BUSINESS AND SOCIAL SCIENCES

Vol. 10, No. 7, July, 2020, E-ISSN: 2222-6990 @ 2020 HRMARS

the maintenance order. The main purpose of the BSK is to manage enforcement of maintenance order, especially for child maintenance. At the same time, to improve the management system in each state and to provide maintenance deposit for qualified applicants to ease the burden of the family.

ii. Creating an e-maintenance system by JKSM in 2012 for monitoring the execution of the maintenance orders decided by Syariah Court. This system is integrated with the e-Syariah system which provide information on whom violate the maintenance order. Through the integration of the system, BSK can monitor any non-compliant maintenance orders; and

iii. Proposed a special handling of maintenance cases in the Syariah High Court and the Shariah Lower Court, as well as establish the Enforcement Division at the Shariah Court.

The steps that were underlined is significant to guarantee the decisions made by the Shariah Court to be effective and efficient. The proposal has been approved by Malaysian ministers on May 8, 2019, and the further actions have been made by JKSM to make the plan and proposal to a success.

\section{Application of Judgement Debtor Summons and Judgement Notice in Penang}

As our discussion above, the study found that in case a father fails to abide the order, the default sum became a debt and it must be paid in full. This consequence has been emphasized by the shariah law, in Section 77 of the Islamic Family Law Enactment (Pulau Pinang, 2004), where child maintenance is considered as the liability of a father if he fails to pay. Also, Section 133 of the same legislation has underlined that if there were arrears, then the shariah court may order to levy the sum involved according to the existing law, or to penalize imprisonment for not more than a month on every month he has failed to oblige the duty. Mother of the child have the right to file a claim for arrears maintenance through a process that is known by judgement debtor summons (Saman Penghutang Penghakiman) and judgement notice (Notis Penghakiman). In Penang, the jurisdiction to handle the case was under the responsibility of the Family Support Section, Department of the Shariah Court of Malaysia (Saberi, 2019).

Through judgement debtor summons that was underlined by Section 176 (Pulau Pinang, 2004), the default father will get summon from the shariah court after failing to pay his child maintenance order. Based on the summon, the father will present at the court in charge and will be investigated by the judge on reasons of his negligence. Then, a ruling will be made and consequently, the father must take it by paying the amount instructed. However, if the father continuously disregards the order and a second report has been made, then a judicial notice under Section 179 will be issued (Pulau Pinang, 2004). The father must provide strong reasons on his recurring defaults and pay a lump sum of the outstanding amount or otherwise he will be imprisoned. This is because the father has committed an offence of contempt of court. In a case a father missing and unable to turn up before the court in charge, an arrest warrant will be issued to him (Salleh, 2019). As a result, these series of lawsuits on the default of child maintenance will ensure the arrears will be collected back fully.

The study also found that the welfare of children, in this case, is an utmost consideration that must be upheld. The point is neglecting children maintenance will cause several harms to the kids, especially in their everyday expenses. Children who happened to live in such conflict of divorceparent, polygamy family or problematic father such as a drug addict, will develop that kids with that atmosphere as vulnerable children who need special protection. Thus, their rights must be given a 
INTERNATIONAL JOURNAL OF ACADEMIC RESEARCH IN BUSINESS AND SOCIAL SCIENCES Vol. 10, No. 7, July, 2020, E-ISSN: 2222-6990 @ 2020 HRMARS

high priority and concern from authorities (Makhtar et. al., 2017). Delay in the safeguarding of their rights will delay the welfare of their lives. Many of these problems associated with the lack of responsibility of former husband/father towards his children especially in providing care, either emotionally or financially.

Therefore, in Penang, any claims related to the default father towards his child maintenance order by the Syariah court, should be forwarded to the Implementation and Enforcement Unit of the Family Support Division (BSK), Penang Syariah Judicial Department. In the year 2018, there were 43 claims were made about arrears child maintenance as portrayed by below statistic in Table 2:

Table 2: Child Maintenance's Claim in Penang 2018

\begin{tabular}{|l|c|c|}
\hline \multicolumn{1}{|c|}{ Month } & Registration & Resolved \\
\hline January & 3 & 2 \\
\hline February & 4 & - \\
\hline March & 1 & 1 \\
\hline April & 2 & 2 \\
\hline May & 7 & 3 \\
\hline June & 4 & 4 \\
\hline July & 2 & 3 \\
\hline August & 11 & 7 \\
\hline September & 2 & 1 \\
\hline October & 3 & 1 \\
\hline November & 1 & 2 \\
\hline December & 3 & 4 \\
\hline Total & 43 & 30 \\
\hline
\end{tabular}

Source: The Syariah Judiciary Department of Penang

Based on the above Table 2, the total number of cases that were registered in 2018 was 43 cases and only 30 cases or around 70 per cent were successfully resolved. The highest case registered as well as being resolved is in August, which is 11 and 7 cases respectively. The second highest registered was in May by 7 cases and share equally by June and December at 4 cases. In average, registration case was 3.5 cases per month while resolving the case was 2.5 cases per month. This means that the registration case precedes the resolved case by 1 case. While the remainder of the cases of 2018 will be brought to the year 2019 as each case is still pending in court. In overall, the type of cases registered was in the of form judgement debtor summons. And only four cases are registered in the form of judicial notice, that was, one case in April and three cases in May (Saberi, 2019).

The settlement of arrears child maintenance claim of the year 2018 has been resolved through two ways, firstly through discussion of both parties under the supervision of the Syariah court officer from the Section of family support; and secondly through an order of the Syariah court. There were two cases where a mother has withdrawn the claim after agreed on mutual arrangement between parties 
INTERNATIONAL JOURNAL OF ACADEMIC RESEARCH IN BUSINESS AND SOCIAL SCIENCES Vol. 10, No. 7, July, 2020, E-ISSN: 2222-6990 @ 2020 HRMARS

(Nik Saberi, 2019). The number of settlements or sums that have been collected through the trial was shown in Table 3 below:

Table 3: Sum Collected of Arrears Child Maintenance Claim 2018

\begin{tabular}{|c|c|c|c|}
\hline No. & No. of Mal Cases & Date of Order & Amount \\
\hline 1 & 07003-037-0109-2016 & $9 / 24 / 2018$ & RM3,490.00 \\
\hline 2 & 07004-037-0290-2017 & $2 / 22 / 2018$ & withdrew \\
\hline 3 & 07004-037-0350-2017 & $8 / 10 / 2018$ & $\mathrm{RM} 2,250.00$ \\
\hline 4 & 07400-037-0089-2017 & $8 / 10 / 2018$ & RM12,300.00 \\
\hline 5 & 07100-037-0298-2017 & $6 / 28 / 2018$ & RM10,000.00 \\
\hline 6 & 07200-037-0101-2017 & $1 / 10 / 2018$ & RM253,100.00 \\
\hline 7 & 07002-037-0294-2017 & $12 / 4 / 2018$ & RM15,050.00 \\
\hline 8 & 07100-037-0197-2017 & $11 / 29 / 2018$ & RM15,800.00 \\
\hline 9 & 07100-037-0184-2017 & $7 / 27 / 2018$ & withdrew \\
\hline 10 & 07001-037-0061-2018 & $4 / 12 / 2018$ & $\mathrm{RM} 11,700.00$ \\
\hline 11 & 07001-037-0250-2018 & $5 / 9 / 2018$ & RM10,500.00 \\
\hline 12 & 07002-037-0106-2018 & $6 / 26 / 2018$ & RM18,000.00 \\
\hline 13 & 07002-037-0359-2018 & $6 / 27 / 2018$ & RM2,660.00 \\
\hline 14 & 07002-037-0547-2018 & $8 / 7 / 2018$ & RM4,600.00 \\
\hline 15 & 07002-037-0610-2018 & $8 / 30 / 2018$ & RM5,900.00 \\
\hline 16 & $07004-037-0257-2018$ & $7 / 4 / 2018$ & RM4,900.00 \\
\hline 17 & 07004-037-0264-2018 & $7 / 25 / 2018$ & $\mathrm{RM} 1,700.00$ \\
\hline 18 & 07100-037-0124-2018 & $6 / 7 / 2018$ & RM7,600.00 \\
\hline 19 & 07100-037-0125-2018 & $7 / 10 / 2018$ & RM3,550.00 \\
\hline 20 & 07400-037-0084-2018 & $9 / 13 / 2018$ & RM23,200.00 \\
\hline 21 & 07001-037-0680-2018 & $12 / 6 / 2018$ & RM25,954.00 \\
\hline 22 & 07002-037-0871-2018 & $12 / 4 / 2018$ & RM2,400.00 \\
\hline 23 & 07003-037-0167-2018 & $12 / 5 / 2018$ & RM20,900.00 \\
\hline 24 & 07200-037-0184-2018 & $11 / 29 / 2018$ & RM15,500.00 \\
\hline 25 & $07200-037-0294-2018$ & $12 / 6 / 2018$ & RM20,000.00 \\
\hline 26 & 07001-037-0061-2018 & $4 / 12 / 2018$ & RM11,700.00 \\
\hline 27 & 07001-037-0250-2018 & $5 / 9 / 2018$ & RM10,500.00 \\
\hline 28 & 07001-076-0596-2017 & $4 / 12 / 2018$ & RM14,730.00 \\
\hline 29 & 07100-076-0044-2018 & $5 / 24 / 2018$ & $\mathrm{RM} 33,880.00$ \\
\hline 30 & 07002-076-0355-2018 & $5 / 29 / 2018$ & RM11,433.00 \\
\hline \multicolumn{3}{|c|}{ TOTAL } & RM573,297.00 \\
\hline
\end{tabular}

Source: The Syariah Judiciary Department of Penang 
INTERNATIONAL JOURNAL OF ACADEMIC RESEARCH IN BUSINESS AND SOCIAL SCIENCES Vol. 10, No. 7, July, 2020, E-ISSN: 2222-6990 @ 2020 HRMARS

In the year 2018, the Syariah court succeeded in collecting RM573,297 of arrears child maintenance claim. The highest collection was RM253,100.00 that was recorded in January from last year case. It was followed by amount RM33,880.00. According to Saberi (2019), most of the cases have been resolved after a father was summoned to be imprisoned if he fails to pay the full cost. Meanwhile, the minimum amount of arrears child maintenance case in the Table 02 was RM1,700.00 that was recorded in July. Based on 43 registered cases, only four cases that involved judgement notice which may imprison a father who fails to pay the overdue amount. And the rest was cases under judgement debtor summon.

Based on statistics that were provided by the Penang Family Support Division (Saberi, 2019), it portrays that there were many cases involving arrears of child maintenance. However, the Division has greatly played its roles in assisting mothers to reclaim the money that was well-ordered by the shariah court. The commitment of the shariah court in establishing the Section of Family Support facilitates the issue of fathers' failure in paying his children maintenance. The arrears were collected in many ways such as by instalment, two or three times of payment and payment in full. Besides, Employees' Provident Fund (EPF) withdrawals are also allowed to be handed over to the mother when the father's retirement money is permitted to be withdrawn. A transfer of property is also allowed when the parties have agreed to swap permanent property such as a house, land or car for the exchange of the amount due. If a father is employed and has an employer, the deduction can also be made through the order of the detention of income. As a result, the child's arrears maintenance will be settled, and the father was able to pay the amount due effectively (Tukiman, 2018).

As consequences on debts of child maintenance after the shariah court order, the state law has provided measures to claim the arrears. The claim shall be made through one of the following processes (Zin, 2007), that were underlined under the Syariah Court Civil Procedure Enactment (Pulau Pinang, 1999):

a) Enforcement of judgement, where any judgement that has been ordered by the shariah court shall be enforced based on Section 148, for payment of money. Based on the said provision, a judgement or an order for the disbursement of money, maybe enforced by one or more of the following means, such as by order of seizure and sale, or hiwalah proceedings, or by order of committal (based on Section 151).

b) Execute order through seizure and sale under Section 160, where the bailiff shall, unless the property seized be money, proceed to sell the property following the provisions.

c) Execute order through seizure and delivery under Section 163. Where execution is ordered by seizure and delivery of a chattel, the bailiff shall seize the chattel and upon payment of all expenses due shall deliver it to the judgement creditor.

d) Execute an enforcement of a judgement for possession of immovable property through Section 149, and

e) Execution of hiwalah through Section 161, where the muhal 'alaih may pay to the bailiff the amount claimed or may deliver to him the property attached.

All of these procedures will guarantee arrears of child maintenance will be disbursed back to them after selling of such assets. 
The enforcement of children maintenance must make use of every provision of laws in the Enactment. As in the finding, the application of judgement debtor summons (Section 176) and judicial notice (Section 179) in the current law will enforce a default father to abide the order fully. This is because no one will endure to be imprisoned for a slight offence. The value was under his capability as the court has gone through many aspects before deciding the amount. This practice has benefited everyone, following the spirit of Islam that benefits the whole world (Sulong, 2019).

\section{Conclusion}

Child maintenance is a major responsibility that a father must fulfil. Islam considered it as debts for the default father who maltreat his children. Failure to do so can result in harm to children as it may affect their quality of life, education and medical treatment. Therefore, Penang Syariah courts have taken an essential move to set up the Family Support Division to help certain wife in claiming the right of her children. Through judgement debtor summon and judgement notice, the shariah court can force a possible father to carry out his religious responsibilities in full of consciousness. Through these law enforcements, a father may be imprisoned for a month or several months according to the default months to pay the arrears. Other alternative enforcement such as through seizure and sale of one's father's assets can also overcome these barriers and guarantee the rights of the child to get the arrears through various angles.

Theoretically, this study has shown the significance of enforcement of two provisions in the Enactment of the Islamic Family Law to claim the child maintenance arrears. The enforcement agency, that is, the Family Support Division provides assistance in comprehending the provision as well as to recover the outstanding debts that the court has ordered. Contextually, there is no compromise for a default father to pay for the arrears because the failure to pay can harm his children. Moreover, if the defendant has a lot of commitments such as daily bills, car instalment, house rent, school expenses and etceteras, it is the priority to abide so in full payment. In this case, the role of the Family Support Division has given a shoulder for every affected mothers to cry on and earn her rights.

Through the enforcement of the twofold provision, the child maintenance arrears have been successfully collected to almost half a million from the 30 cases resolved in 2018, which were concentrated in Penang only. Of all the cases resolved, only two cases were withdrawn, and the rest of the cases have been solved successfully with the full payment. The move to enforce childmaintenance payment using judgement debtor summons and judicial notice has made the claim process easy to implement and fast-paced by the father. And hence, this finding shows that enforcement of existing laws needs to be fully implemented, in light of the existing court orders. Therefore, this allows the role of the Shariah Courts to be fully utilized in securing the rights of children especially in the context of child maintenance arrears.

\section{Acknowledgements}

This research was supported by the Book Grant that was provided by the Universiti Sains Malaysia, Pulau Pinang, Malaysia. 
INTERNATIONAL JOURNAL OF ACADEMIC RESEARCH IN BUSINESS AND SOCIAL SCIENCES

Vol. 10, No. 7, July, 2020, E-ISSN: 2222-6990 @ 2020 HRMARS

\section{References}

Abu Hassan, A. W. (2016). The rights of women under Islamic family law in Malaysia [Hak-hak wanita menurut undang-undang keluarga Islam di Malaysia]. Selangor: Universiti Islam Antarabangsa.

Ali, M. S. A., \& Arshad, A. (2014). Claiming Maintenance from Children: The Malaysian Legal Perspective. Global Journal of Business and Social Science Review. 2 (1), 11-17.

Al-Shirbini, S. M. K. (2001). Mughni al-Muhtaj. Beirut: Dar al-Fikr.

Asni, F. M., \& Sulong, J. (2017a). The Analysis of Practices and Methods of Fatwa Standardisation in Malaysia and Pakistan. Islamic Quarterly, 61(2), 155-186.

Asni, F. M., \& Sulong, J. (2017b). Penyelarasan Fatwa antara negeri-negeri: Analisis Amalan dan Kaedah Penyeragamannya di Malaysia [Coordination of fatwas between states: An analysis of practices and methods of standardization in Malaysia]. Jurnal INFAD, 9(1), 87-109.

Brooks-Gunn J., \& Duncan G. J. (1997). The effects of poverty on children. Future Child, 7(2), 55-71.

Howell, K. E. (2013). Introduction to the Philosophy of Methodology. London: Sage Publications. http://www.jksm.gov.my/images/menuMedia/siaranakhbar/2018/11/0911\%20sh\%20\%20Sek at\%20Bank,\%20Potong\%20Wang\%20Dari\%20Akuan\%20Bekas\%20Suami.pdf.

Ibrahim, B., \& Mohd, A. (2013). Hak anak terhadap nafkah dalam Perundangan Islam: Sejauh manakah bapa bertanggungjawab menanggung nafkah anaknya [The child's right to the maintennace in Islamic Law: To what extent is the father responsible for the maintenance of his child]. Kanun, 25(2), 255-272.

Ismail, I. S. (2018). Sekat akaun bank bekas suami [Impeding Ex-Husband's Bank Account]. Berita Harian. Retrieved from https://www.pressreader.com/malaysia/berita-harianmalaysia/20181108/281543701939968.

Jamaludin, M. H., \& Buang, A. H. (2017). Syariah courts in Malaysia and the development of Islamic jurisprudence: The study of istihsan. International Journal of Nusantara Is/am, 1(1), 1-12.

Makhtar, M., Asari, K. A., Pauzai, N. A., \& Abdullah Asuhaimi, F. (2017). Children's Right to Education: Financial Neglect after Divorce in Muslim Marriage in Malaysia. Pertanika Journal of Social Science \& Humanities, 25(s), 179-184.

Nasohah, Z. (2018). Analysis on shariah court decision over the determination of rate and form of child maintenance. $3^{\text {rd }}$ International Seminar on Islamic Thought, 287-294.

Parliament. (2019). Dewan Rakyat: Second Meeting, Second Term, $12^{\text {th }}$ Parliament. Oral Answer to Question no. 140 by Azalina Othman Said. 9 July 2019.

Pelto, P. J. (2017). Mixed methods in ethnographic research: Historical perspectives. New York \& London: Routledge.

Pulau Pinang. (1999). Syariah Court Civil Procedure (State of Penang) Enactment. No. 4. Penang: Government Press.

Pulau Pinang. (2004). Islamic Family Law (State of Penang) Enactment. No. 3. Penang: Government Press.

Razali, M., \& Sulong, J. (2016). Amalan penulisan penghakiman dan pelaksanaannya di Mahkamah Syariah Malaysia [The practice of judgment's writing and its implementation in the Malaysian Syariah Court]. Jurnal Syariah, 24(1), 25-58.

Saberi, N. S. (2019). Assistant Director at the Section of Family Support, Penang Shariah Court. Interviewed on 21 July 2019, $3.00 \mathrm{pm}$.

Salleh, M. F. (2018). Child abuse: We are not doing enough about it. New Straits Times. Retrieved at https://www.nst.com.my/news/exclusive/2018/10/418676/child-abuse-we-are-not-doing- 
INTERNATIONAL JOURNAL OF ACADEMIC RESEARCH IN BUSINESS AND SOCIAL SCIENCES

Vol. 10, No. 7, July, 2020, E-ISSN: 2222-6990 @ 2020 HRMARS

enough-about-

it\#: :text=The\%20New\%20Straits\%20Times\%20were,children\%20and\%20prosecute\%20the\% 20perpetrators.

Salleh, M. W. (2019). Assistant Shariah Officer at the Section of Family Support, Penang Shariah Court. Interviewed 21 July 2019, 4.00 pm.

Sulong, J. (2019). "Istinbat Rahmatan lil 'Alamin: Perspektif Usul al-Fiqh". In Shukran Abd Rahman, Haslina Ibrahim (Eds.), Rahmatan lil 'Alamin dalam konteks Masyarakat Kontemporari. Kuala Lumpur: MAIWP dan IRKH UIA, 84-93.

Tukiman, S. (2018). Sekat bank, potong wang dari akaun bekas suami [Block bank deduct money from the ex-husband's account]. Sinar Harian. Retrieved at

Walliman, N. (2011). Research Methods the Basic. New York: Routledge.

Willis, J. W. (2007). Foundations of qualitative research: interpretive and critical approaches. https://dx.doi.org/10.4135/9781452230108. Retrieved 28 May 2020.

Zin, M. N. (2007). Islamic family law [Undang-undang Keluarga Islam]. Kuala Lumpur: Dewan Bahasa dan Pustaka. 